\title{
Role of HSP27 in tumor necrosis factor- $\alpha$-stimulated interleukin-6 synthesis in osteoblasts
}

\author{
KENJI KATO ${ }^{1,2}$, HARUHIKO TOKUDA ${ }^{2,3}$, JUN MIZUTANI ${ }^{1}$, SEIJI ADACHI ${ }^{2}$, RIE MATSUSHIMA-NISHIWAKI ${ }^{2}$, \\ HIDEO NATSUME $^{1,2}$, OSAMU KOZAWA ${ }^{2}$ and TAKANOBU OTSUKA ${ }^{1}$ \\ ${ }^{1}$ Department of Orthopedic Surgery, Nagoya City University Graduate School of Medical Sciences, Nagoya 467-8602; \\ ${ }^{2}$ Department of Pharmacology, Gifu University Graduate School of Medicine, Gifu 501-1194; ${ }^{3}$ Department \\ of Clinical Laboratory, National Center for Geriatrics and Gerontology, Obu, Aichi 474-8511, Japan
}

Received May 30, 2011; Accepted July 4, 2011

DOI: $10.3892 /$ ijmm.2011.762

\begin{abstract}
Heat shock protein 27 (HSP27) is known to act as a molecular chaperone. We have recently reported that HSP27 regulates osteocalcin synthesis in osteoblast-like MC3T3-E1 cells. In the present study, we investigated the role of HSP27 in tumor necrosis factor- $\alpha$ (TNF- $\alpha$ )-stimulated interleukin- 6 (IL-6) synthesis in MC3T3-E1 cells. The levels of IL-6 release and IL- 6 mRNA stimulated by TNF- $\alpha$ in MC3T3-E1 cells transfected with HSP27 was significantly higher than those in the control cells. In addition, the levels of secreted IL- 6 and IL-6 mRNA in the phospho-mimic HSP27-overexpressing cells were significantly higher than those in the non-phosphorylatable HSP27-overexpressing cells. Furthermore, we observed no significant differences in the phosphorylation levels of $\mathrm{I} \kappa \mathrm{B} /$ $\mathrm{NF \kappa B}, \mathrm{Akt}$, and p44/p42 mitogen-activated protein kinase among the 4 types of transfected cells. Therefore, these results strongly suggest that HSP27 enhances TNF- $\alpha$-stimulated IL-6 synthesis, and that the phosphorylation status of HSP27 is related to IL-6 synthesis in osteoblasts.
\end{abstract}

\section{Introduction}

Tumor necrosis factor- $\alpha$ (TNF- $\alpha)$ is a multifunctional cytokine which is involved in various conditions such as cancer, inflammation and infection, and it induces numerous physiological effects on a variety of cells (1-3). Bone metabolism is regulated mainly by two functional cells, osteoblasts and osteoclasts, which are responsible for bone formation and bone resorption, respectively (4). TNF- $\alpha$ is recognized as an inflammatory cytokine and is one of the most potent osteoclastogenic factors; accordingly, it is considered as a

Correspondence to: Dr Osamu Kozawa, Department of Pharmacology, Gifu University Graduate School of Medicine, Yanagido 1-1, Gifu 501-1194, Japan

E-mail: okozawa@gifu-u.ac.jp

Key words: tumor necrosis factor- $\alpha$, interleukin-6, heat shock protein 27 , phosphorylation, osteoblasts bone resorptive agent (3). In osteoblasts, TNF- $\alpha$ stimulates the synthesis of interleukin-6 (IL-6), which is a pleiotropic cytokine that has important physiological effects on a wide range of functions, such as promoting $\mathrm{B}$ cell differentiation, T-cell activation and inducing acute phase proteins $(5,6)$. We have previously reported that TNF- $\alpha$ stimulates IL- 6 synthesis through the activation of p44/p42 mitogen-activated protein kinase (MAPK) and phosphatidylinositol 3-kinase (PI3K)/ Akt in osteoblast-like MC3T3-E1 cells (7-9). IL-6 stimulates bone resorption and induces osteoclast formation $(2,6,10,11)$. Together, these findings suggest that the IL- 6 secreted after TNF- $\alpha$ stimulation of osteoblasts plays a key role as a downstream effector of bone resorption during bone metabolism.

Heat shock proteins (HSPs) are induced in response to various types of stress such as heat stress and chemical stress (12). HSPs are generally classified into two categories, high-molecular-weight HSPs and low-molecular-weight HSPs (small HSPs) according to their molecular sizes $(13,14)$. Highmolecular-weight HSPs such as HSP70, HSP90 and HSP110 have been well investigated and are recognized to act as molecular chaperones which contribute to various effects including protein folding, oligomerization and protection of cells from apoptosis $(12,15)$. In contrast, although small HSPs with a molecular mass from 10 to $30 \mathrm{kDa}$, such as HSP27, $\alpha \mathrm{B}$-crystallin and HSP20 are constitutively expressed in various tissues, their functions have not yet been well investigated. Small HSPs have recently been reported to be implicated in some diseases. For example, a mutation of $\alpha \mathrm{B}$-crystallin contributes to cardiac myopathy (16). Overexpressed HSP27 and $\alpha \mathrm{B}$-crystallin protect heart cells against ischemia/reperfusion injury, similarly to HSP70 (17). It has also been reported that $\alpha \mathrm{B}$-crystallin is overexpressed in oligodendrocytes and astrocytes of multiple sclerosis patients, and as for cancer, a strong correlation exists between lymph node involvement and overexpressed $\alpha \mathrm{B}$-crystallin in primary breast carcinoma $(18,19)$.

HSP27 has three serine residues (Ser-15, Ser-78 and Ser-82) that can be phosphorylated, and it normally exists in an unphosphorylated aggregated form. When HSP27 is phosphorylated, it changes from an aggregated form to a dimer $(20,21)$. We have previously reported the levels of phosphorylated HSP27 to be inversely correlated with the progression of human hepatocellular carcinoma (22). 
In osteoblasts, HSP27 has been reported to be involved in the balance between differentiation and apoptosis $(23,24)$. Although the expression level of HSP27 differs by cell type (25-27), in unstimulated osteoblasts, the expression level of HSP27 is reportedly very low (28). On the other hand, we have previously reported that various physiological stimuli are able to cause the induction of HSP27 in osteoblast-like MC3T3-E1 cells (29-33). We have also reported that MAPKs play a role in prostaglandin D2-induced phosphorylation of HSP27 in MC3T3-E1 cells (9), and that phosphorylated HSP27 is concentrated perinuclearly in these cells (34). However, the exact function of HSP27 in bone metabolism has not been satisfactorily clarified. In the present study, we investigated the role of HSP27 in the IL- 6 synthesis stimulated by TNF- $\alpha$ in osteoblast-like MC3T3-E1 cells.

\section{Materials and methods}

Materials. TNF- $\alpha$ was obtained from Funakoshi Pharmaceutical Co. (Tokyo, Japan). Anisomycin was purchased from Calbiochem-Novabiochem (La Jolla, CA). Antibodies against HSP27 and glyceraldehyde-3-phosphate dehydrogenase (GAPDH) were purchased from Santa Cruz Biotechnology, Inc. (Santa Cruz, CA). Antibodies against phospho-specific IкB, phospho-specific NFKB, and phospho-specific HSP27 (Ser-82) were obtained from Cell Signaling, Inc. (Beverly, MA). The ECL Western blotting detection system was obtained from GE Healthcare UK Ltd. (Buckinghamshire, UK). Other materials and chemicals were obtained from commercial sources. Anisomycin was dissolved in dimethyl sulfoxide (DMSO). The maximum concentration of DMSO was $0.1 \%$, which did not affect the assay for IL- 6 or detection of protein expression by Western blot analysis.

Cell culture. Cloned osteoblast-like MC3T3-E1 cells derived from newborn mouse calvaria (35) were maintained as previously described (36). Briefly, the cells were cultured in $\alpha$-minimum essential medium ( $\alpha$-MEM) containing $10 \%$ fetal calf serum (FCS) at $37^{\circ} \mathrm{C}$ in a humidified atmosphere of $5 \%$ $\mathrm{CO}_{2} / 95 \%$ air. The cells were seeded in $35-\mathrm{mm}\left(5 \times 10^{4}\right.$ cells $)$ or $90-\mathrm{mm}\left(2 \times 10^{5}\right.$ cells $)$ diameter dishes in $\alpha$-MEM containing $10 \%$ FCS. After 5 days, the medium was exchanged to fresh $\alpha$-MEM containing $0.3 \%$ FCS. The cells were then used for experiments after $48 \mathrm{~h}$.

Establishment of cells stably transfected with HSP27. Mutant-HSP27 plasmids, in which serine residues (Ser-15, Ser-72 and Ser-82) were mutated to alanines to generate constitutively non-phosphorylatable HSP27 (3A), or were mutated to aspartic acid, to generate constitutively phosphomimic HSP27 (3D), were kindly provided by Dr C. Schafer (Klinikum Grosshadern, Ludwig-Maximilians University, Munich, Germany). For stable transfections, MC3T3-E1 cells ( $5 \times 10^{5}$ cells) were cultured in 6-well dishes and then transfected with $2 \mu \mathrm{g}$ of the wild type (WT) or mutant HSP27 plasmids expressing geneticin (G418; EMD Chemicals, Inc., San Diego) resistance using $12 \mu \mathrm{l}$ of the UniFECTOR transfection reagent (B-Bridge International, Mountain View, CA) in $1 \mathrm{ml}$ of $\alpha$-MEM medium without FCS. One milliliter of medium with $10 \%$ FCS was added $5 \mathrm{~h}$ after transfection. The cells were then incubated in the presence of $400 \mu \mathrm{g} / \mathrm{ml}$ of G418. After 2 weeks, single G418-resistant colonies were obtained by serial dilution in 96-well dishes. The colonies were then maintained and analyzed individually for the expression of HSP27.

Western blot analysis. The cultured cells were stimulated by $30 \mathrm{ng} / \mathrm{ml}$ of TNF- $\alpha$ in $\alpha$-MEM containing $0.3 \%$ FCS for the indicated periods. The cells were washed twice with phosphatebuffered saline and then lysed, homogenized and sonicated in a lysis buffer containing $62.5 \mathrm{mM}$ Tris- $\mathrm{HCl}, \mathrm{pH}$ 6.8, 2\% SDS and $10 \%$ glycerol. SDS-polyacrylamide gel electrophoresis (PAGE) was performed according to Laemmli (37) on $10 \%$ polyacrylamide gels. A Western blot analysis was performed as previously described (38) using antibodies against phospho-

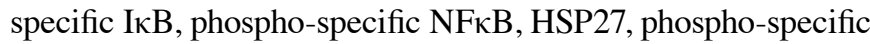
HSP27 and GAPDH with peroxidase-labeled antibodies as secondary antibodies. The peroxidase activity on the PVDF sheet was visualized on X-ray film by means of the ECL Western blot analysis detection system.

IL-6 assay. The cultured cells were stimulated by $30 \mathrm{ng} / \mathrm{ml}$ of TNF- $\alpha$ in $1 \mathrm{ml}$ of $\alpha$-MEM containing $0.3 \%$ FCS for the indicated periods. The conditioned medium and cell lysates were collected at the end of the incubation. The IL- 6 concentration was measured by an IL-6 enzyme-linked immunosorbent assay (ELISA) kit (R\&D Systems, Inc., Minneapolis, MN). The absorbance of ELISA samples was measured at 450 and $560 \mathrm{~nm}$ with an EL 340 Bio Kinetic Reader (Bio-Tek Instruments, Inc., Winooski, VT). The levels of IL-6 release were adjusted for the respective whole cell lysates.

Real-time RT-PCR. The cultured cells were stimulated by $30 \mathrm{ng} / \mathrm{ml}$ of TNF- $\alpha$ for the indicated periods. Total-RNA was isolated and transcribed into cDNA using the TRIzol reagent and an Omniscript Reverse Transcriptase kit. Realtime RT-PCR was performed using a Light Cycler system (Roche Diagnostics) in capillaries and the Fast-Start DNA Master SYBR-Green I provided with the kit. Sense and antisense primers for mouse IL-6 mRNA were purchased from Takara Bio, Inc. (Tokyo, Japan) (primer set ID: MA039013). The amplified products were determined by a melting curve analysis and agarose electrophoresis. The IL-6 mRNA levels were normalized to those of GAPDH mRNA.

Statistical analysis. The data were analyzed by ANOVA followed by the Bonferroni method for multiple comparisons between pairs, and $\mathrm{P}<0.05$ was considered significant. All data are presented as the mean \pm SEM of triplicate determinations.

\section{Results}

Effect of TNF- $\alpha$ on HSP27 levels in MC3T3-E1 cells. We have previously reported that HSP27 is induced by various physiological agents in osteoblast-like MC3T3-E1 cells (29-33). Therefore, we first examined the effect of TNF- $\alpha$ alone on the HSP27 levels in these cells. Since HSP27 was induced for up to $24 \mathrm{~h}$ in our previous investigations, we performed experiments to assess the expression of the protein for up to $24 \mathrm{~h}$ by a Western blot analysis. As shown in Fig. 1, TNF- $\alpha$ alone failed to up-regulate the protein levels of HSP27 in MC3T3-E1 cells. 


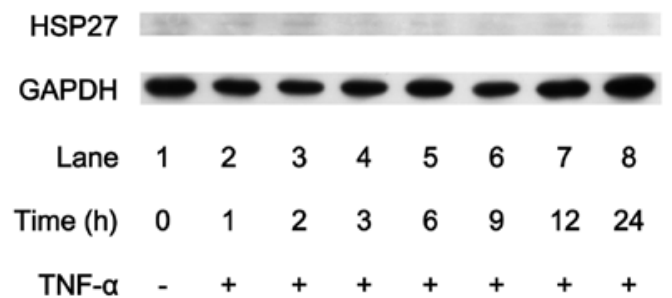

Figure 1. Effect of TNF- $\alpha$ on HSP27 induction in untransfected MC3T3-E1 cells. The cultured cells were stimulated by $30 \mathrm{ng} / \mathrm{ml}$ of TNF- $\alpha$ for the indicated periods. The cell extracts were then subjected to SDS-PAGE with a subsequent Western blot analysis with antibodies against HSP27 and GAPDH.

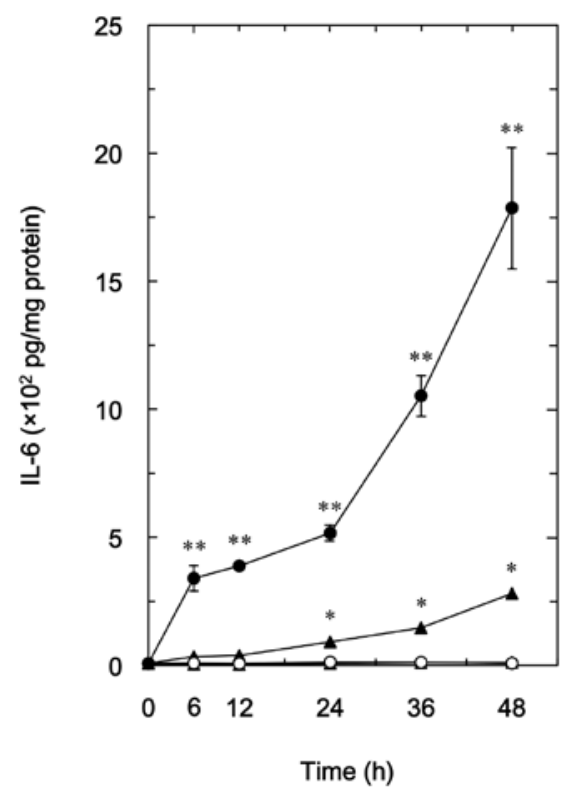

Figure 2. Effect of TNF- $\alpha$ on IL-6 release in the empty and WT cells. The cultured cells were stimulated by $30 \mathrm{ng} / \mathrm{ml}$ of TNF- $\alpha$ ( $\mathbf{\wedge}$, empty; $\bullet$, WT) or vehicle $(\Delta$, empty; $\bigcirc$, WT). The level of IL-6 synthesis was corrected to the total protein level. Each value represents the mean \pm SEM of triplicate independent determinations. ${ }^{*} \mathrm{P}<0.05$, compared to the value of the vehicle in the empty cells. ${ }^{* *} \mathrm{P}<0.05$, compared to the value with TNF- $\alpha$ in the empty cells.

Effect of overexpressed HSP27 on TNF- $\alpha$-stimulated IL-6 release in MC3T3-E1 cells. We have shown that TNF- $\alpha$ stimulates the synthesis and secretion of IL-6 in osteoblast-like MC3T3-E1 cells (8). In order to investigate the role of HSP27 in the TNF- $\alpha$ induced IL- 6 release, we next examined the effect of TNF- $\alpha$ on IL-6 release in WT HSP27 cDNA-transfected MC3T3-E1 cells. As previously shown (34), the 'empty' cells, which were transfected with an empty vector, represent the normal parental MC3T3-E1 cells, and the WT cells represent the MC3T3-E1 cells overexpressing the wild type-HSP27. In our previous report (8), TNF- $\alpha$ stimulated IL- 6 release in a time-dependent manner for up to $48 \mathrm{~h}$ and in a dose-dependent manner in the range between 1 and $30 \mathrm{nM}$ in untransfected MC3T3-E1 cells. According to this report, we examined the effects of TNF- $\alpha$ on IL- 6 release in the range between 1 and $30 \mathrm{nM}$ of TNF- $\alpha$ for up to $48 \mathrm{~h}$ in HSP27-transfected MC3T3-E1 cells. We observed that the IL-6 release stimulated by TNF- $\alpha$ was time- and dose-dependent in both the WT cells and the empty cells (Figs. 2 and 3). However, the level of IL-6 released from the WT cells was significantly

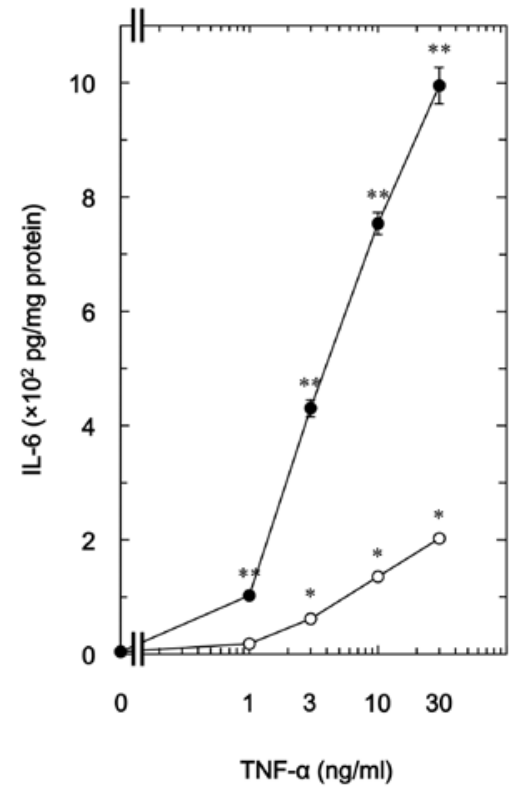

Figure 3. Dose-dependent effects of TNF- $\alpha$ on IL- 6 release in the empty and WT cells. The cultured cells were stimulated by various doses of TNF- $\alpha$ (O, empty; •, WT) for $48 \mathrm{~h}$. The level of IL-6 synthesis was corrected to the total protein level. Each value represents the mean \pm SEM of triplicate independent determinations. " $\mathrm{P}<0.05$, compared to the value of the vehicle in the empty cells. ${ }^{* *} \mathrm{P}<0.05$, compared to the value with TNF- $\alpha$ in the empty cells.

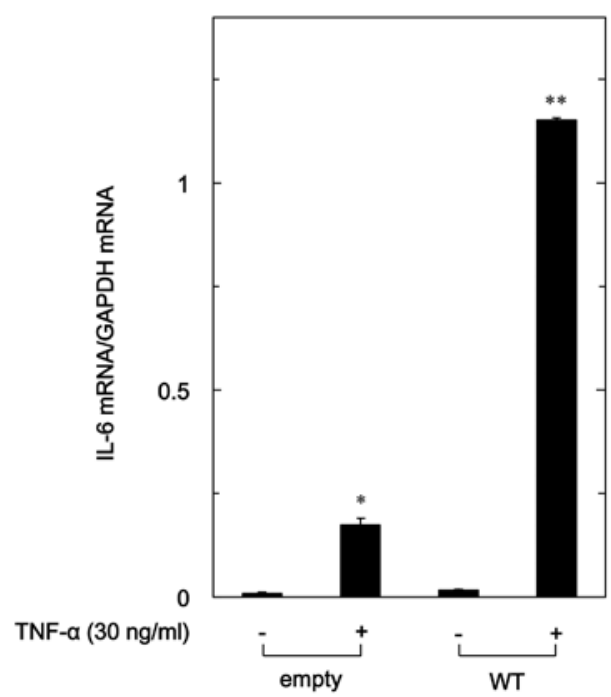

Figure 4. Effects of TNF- $\alpha$ on IL-6 mRNA expression in the empty and WT cells. The empty or WT cells were stimulated by $30 \mathrm{ng} / \mathrm{ml}$ of TNF- $\alpha$ or vehicle for $6 \mathrm{~h}$. Total-RNA was isolated and transcribed into cDNA. The expression of IL- 6 mRNA and GAPDH mRNA were quantified by real-time RT-PCR. The IL-6 mRNA levels were normalized to those of GAPDH mRNA. Each value represents the mean \pm SEM of triplicate independent determinations. " $\mathrm{P}<0.05$, compared to the value of the vehicle in the empty cells. ${ }^{* *} \mathrm{P}<0.05$, compared to the value with TNF- $\alpha$ in the empty cells.

increased compared to that from the empty cells. At $30 \mathrm{nM}$ of TNF- $\alpha$, the level of IL- 6 produced was $(2.03 \pm 0.09) \times 10^{2} \mathrm{pg} / \mathrm{mg}$ protein from the empty cells, while the level in the WT cells was $(9.95 \pm 0.32) \times 10^{2} \mathrm{pg} / \mathrm{mg}$ protein.

Effect of overexpressed HSP27 on the TNF- $\alpha$-stimulated IL-6 $m R N A$ level in MC3T3-E1 cells. TNF- $\alpha$ increases IL-6 mRNA 
A

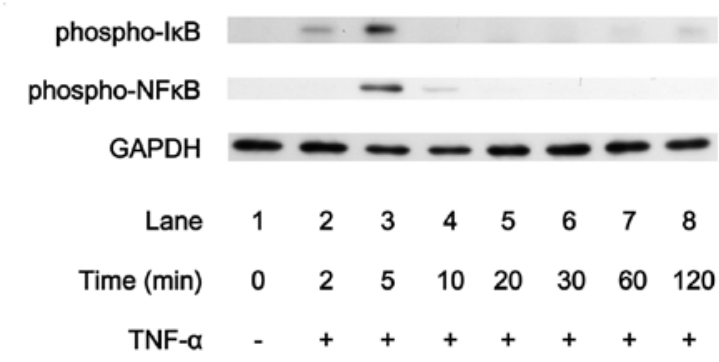

B

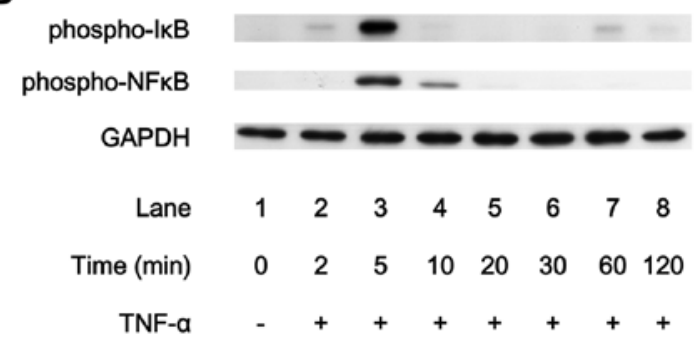

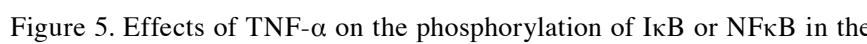
empty and WT cells. The empty cells (A) or the WT cells (B) were stimulated by $30 \mathrm{ng} / \mathrm{ml}$ of TNF- $\alpha$ for the indicated periods. The cell extracts were then subjected to SDS-PAGE with a subsequent Western blot analysis with anti-

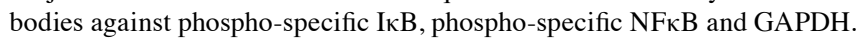

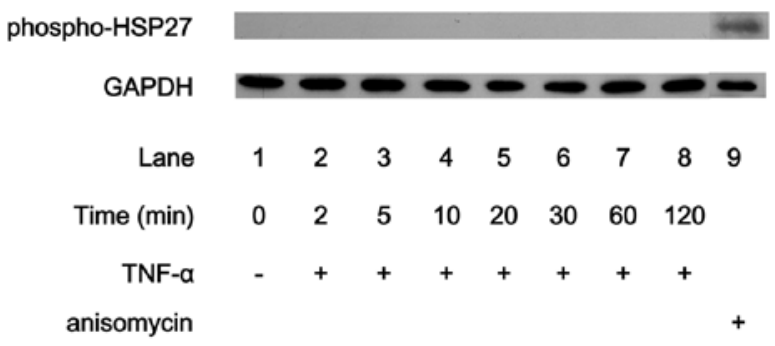

Figure 6. Effect of TNF- $\alpha$ on the phosphorylation of HSP27 in the WT cells. The cultured cells were stimulated by $30 \mathrm{ng} / \mathrm{ml}$ of TNF- $\alpha$ for the indicated periods (lanes 1-8). The cultured cells were stimulated by $10 \mu \mathrm{M}$ of anisomycin for $20 \mathrm{~min}$ (lane 9). The cell extracts were then subjected to SDS-PAGE with a subsequent Western blot analysis with antibodies against phospho-specific HSP27 (Ser-82) and GAPDH.

level as well as IL-6 secretion in osteoblasts (10). To investigate whether the amplifying effect of HSP27 on TNF- $\alpha$-stimulated IL-6 release results from a transcriptional event, we examined the effects of TNF- $\alpha$ on the IL- 6 mRNA expression in the WT cells and the empty cells by real time RT-PCR. As observed for the IL- 6 release, the expression level of IL- 6 mRNA in the WT cells was significantly higher than that in the empty cells (Fig. 4).

Effects of TNF- $\alpha$ on intracellular signaling in the WT HSP27-transfected cells and the empty vector-transfected cells. TNF- $\alpha$ reportedly induces the phosphorylation of I $\mathrm{B}$ and subsequently activates the NFKB signaling pathway (39). We next investigated the effects of TNF- $\alpha$ on intracellular signaling in the WT and the empty cells. TNF- $\alpha$ remarkably

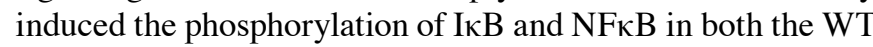

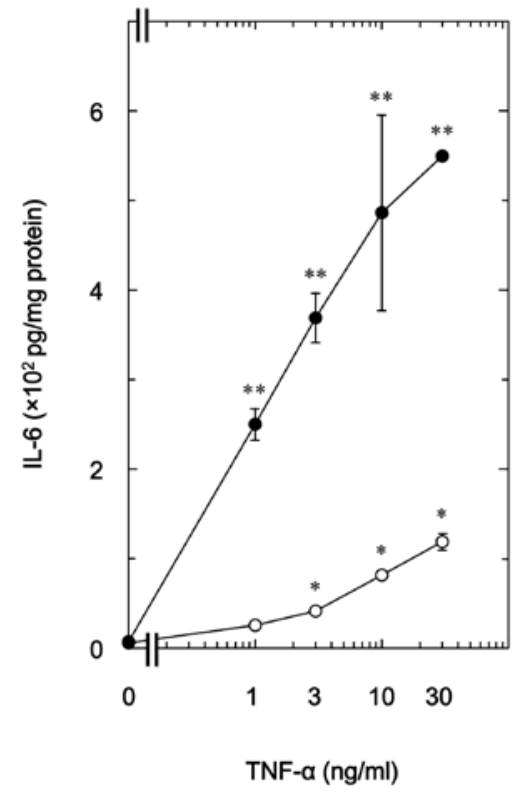

Figure 7. Effects of TNF- $\alpha$ on IL-6 release in 3A or 3D HSP27-transfected MC3T3-E1 cells. The cultured cells were stimulated by various doses of TNF- $\alpha(O, 3 \mathrm{~A} ; \bullet, 3 \mathrm{D})$ for $48 \mathrm{~h}$. The level of IL- 6 synthesis was corrected to the total protein level. Each value represents the mean \pm SEM of triplicate independent determinations. ${ }^{*} \mathrm{P}<0.05$, compared to the value of the vehicle in the $3 \mathrm{~A}$ cells; ${ }^{* * *} \mathrm{P}<0.05$, compared to the value with TNF- $\alpha$ in the $3 \mathrm{~A}$ cells.

cells and the empty cells (Fig. 5). The effect of TNF- $\alpha$ on the phosphorylation of $\mathrm{I} \kappa \mathrm{B}$ reached its peak 2-5 min after stimulation, and decreased thereafter in both cell lines. The effect of TNF- $\alpha$ on the phosphorylation of NFкB in the WT cells and the empty cells was also similar, and the effect reached its peak at $5 \mathrm{~min}$, and decreased thereafter. As shown in Fig. 5, we did not observe any significant differences between the WT and the empty cells.

We have previously reported that TNF- $\alpha$ stimulates IL-6 synthesis, at least in part, through the activation of p44/p42 MAPK and PI3K/Akt in MC3T3-E1 cells $(7,8,40)$. Therefore, we also examined the effects of TNF- $\alpha$ on the phosphorylation of p44/p42 MAPK and Akt in both the WT cells and the empty cells. However, no significant differences were observed in their phosphorylation between the WT cells and the empty cells (data not shown)

Effect of phosphorylated HSP27 on TNF- $\alpha$-stimulated IL-6 release in MC3T3-E1 cells. We next investigated whether the effect of TNF- $\alpha$ on IL- 6 release is affected by the phosphorylation status of HSP27 in MC3T3-E1 cells. At first, we examined the effect of TNF- $\alpha$ alone on the phosphorylation of HSP27 in the WT HSP27 cDNA-transfected cells. As shown in Fig. 6, TNF- $\alpha$ did not induce the phosphorylation of HSP27 until 120 min after the stimulation in the HSP27 overexpressing MC3T3-E1 cells, while anisomycin, an activator of p38 MAPK (41), induced HSP27 phosphorylation as described in our previous report (34). We then examined the effects of TNF- $\alpha$ on IL-6 release in the phospho-mimic HSP27 cDNA-transfected MC3T3-E1 cells (3D cells) compared to that in the nonphosphorylatable HSP27 cDNA-transfected MC3T3-E1 cells (3A cells). TNF- $\alpha$ stimulated IL- 6 release in a dose-dependent manner in the $3 \mathrm{~A}$ and the $3 \mathrm{D}$ cells (Fig. 7). However, the level 


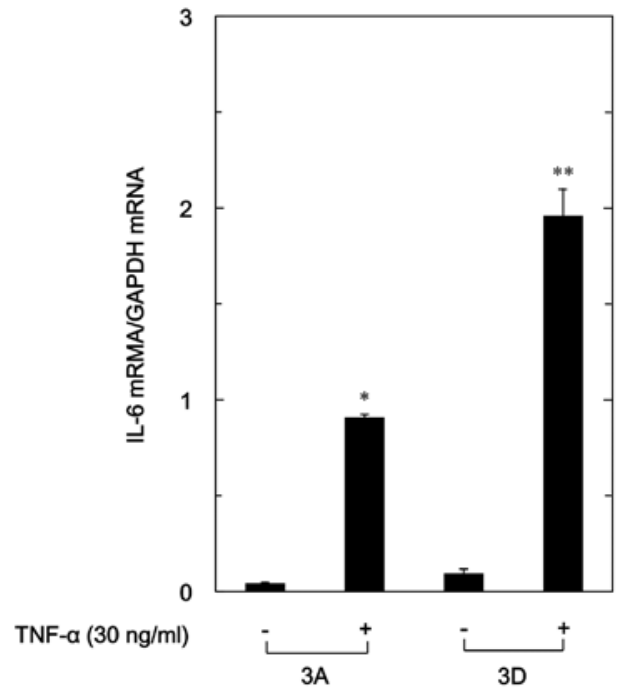

Figure 8. Effects of TNF- $\alpha$ on IL-6 mRNA expression in 3A or 3D HSP27transfected MC3T3-E1 cells. The 3A or 3D cells were stimulated by $30 \mathrm{ng} /$ $\mathrm{ml}$ TNF- $\alpha$ or vehicle for $6 \mathrm{~h}$. Total-RNA was isolated and transcribed into cDNA. The expression of IL-6 mRNA and GAPDH mRNA were quantified by real-time RT-PCR, and the IL- 6 mRNA levels were normalized to those of GAPDH mRNA. Each value represents the mean \pm SEM of triplicate independent determinations. ${ }^{*} \mathrm{P}<0.05$, compared to the value of the vehicle in the $3 \mathrm{~A}$ cells; ${ }^{* *} \mathrm{P}<0.05$, compared to the value with TNF- $\alpha$ in the $3 \mathrm{~A}$ cells.

of IL-6 release in the 3D cells was significantly higher than that in the $3 \mathrm{~A}$ cells. Upon stimulation with $30 \mathrm{nM}$ of TNF- $\alpha$, the level of IL-6 release was $(1.19 \pm 0.09) \times 10^{2} \mathrm{pg} / \mathrm{mg}$ protein in the $3 \mathrm{~A}$ cells, and $(5.50 \pm 0.04) \times 10^{2} \mathrm{pg} / \mathrm{mg}$ protein in the $3 \mathrm{D}$ cells.

Effect of the phosphorylation status of HSP27 on TNF- $\alpha$ stimulated IL-6 mRNA level in MC3T3-El cells. We further investigated whether the effect of phosphorylated HSP27 on increased TNF- $\alpha$-stimulated IL- 6 release is exerted through a transcriptional event by real-time RT-PCR. We observed the expression level of IL-6 mRNA in the 3D cells to be significantly enhanced compared to that in the $3 \mathrm{~A}$ cells (Fig. 8).

Effects of TNF- $\alpha$ on intracellular signaling in the cells overexpressing non-phosphorylatable mutant $3 A-H S P 27$ or the phospho-mimic mutant $3 D$-HSP27. Finally, we examined the effects of TNF- $\alpha$ on intracellular signaling in the 3A and the $3 \mathrm{D}$ cells. TNF- $\alpha$ remarkably induced the phosphorylation of both $\mathrm{I} \kappa \mathrm{B}$ and $\mathrm{NF} \kappa \mathrm{B}$ in the $3 \mathrm{~A}$ cells and the 3D cells (Fig. 9). The effects of TNF- $\alpha$ on the phosphorylation of IкB and $\mathrm{NF \kappa B}$ reached its peak at $5 \mathrm{~min}$ in both cell types. We did not observe any significant differences between the $3 \mathrm{~A}$ and the $3 \mathrm{D}$ cells. We also examined the effects of TNF- $\alpha$ on the phosphorylation of p44/p42 MAPK and Akt in the 3A and the $3 \mathrm{D}$ cells. However, there were also no significant differences in the phosphorylation of $\mathrm{p} 44 / \mathrm{p} 42$ MAPK and Akt between the $3 \mathrm{~A}$ and the $3 \mathrm{D}$ cells (data not shown).

\section{Discussion}

We have previously shown that HSP27 is expressed in unstimulated osteoblast-like MC3T3-E1 cells, however the level is low. Nevertheless, HSP27 expression is induced
A

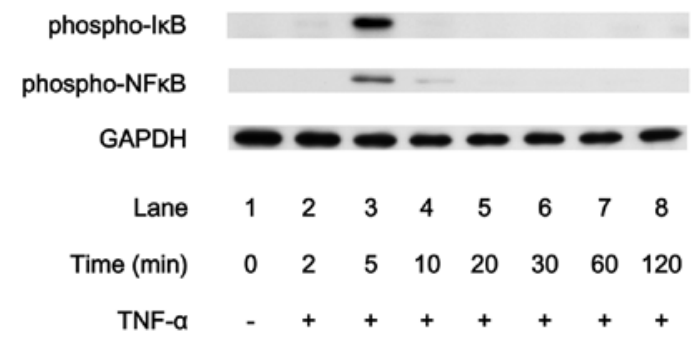

B

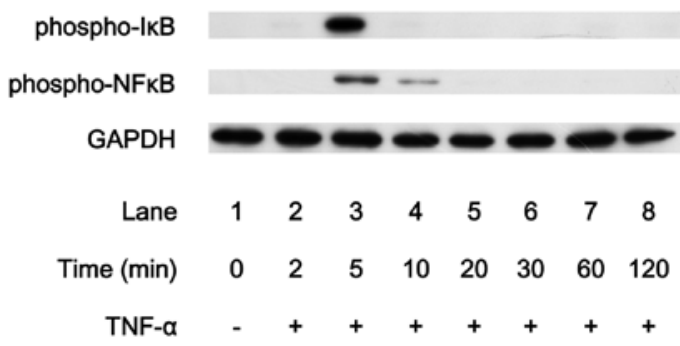

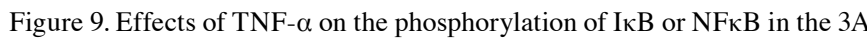
and $3 \mathrm{D}$ cells. The $3 \mathrm{~A}$ cells (A) or the $3 \mathrm{D}$ cells (B) were stimulated by $30 \mathrm{ng} / \mathrm{ml}$ of TNF- $\alpha$ for the indicated periods. The cell extracts were then subjected to SDS-PAGE with a subsequent Western blot analysis with antibodies against

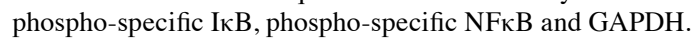

by a variety of physiological agents, such as prostaglandins (29-33). In the present study, we investigated the role of HSP27 on TNF- $\alpha$-stimulated IL- 6 synthesis in osteoblast-like MC3T3-E1 cells transfected to overexpress HSP27. The level of TNF- $\alpha$-stimulated IL- 6 release was significantly increased in the WT HSP27-transfected cells than in the empty vectortransfected cells. In addition, the level of TNF- $\alpha$-stimulated IL-6 mRNA expressed in the WT cells was also enhanced compared to the empty cells. These findings suggest that HSP27 has a stimulatory effect on the TNF- $\alpha$-induced IL- 6 synthesis in osteoblast-like MC3T3-E1 cells. HSP27 is phosphorylated at three serine residues (Ser-15, Ser-78 and Ser-82), and phosphorylation is accompanied with a conformational change (21). We investigated the effects of the phosphorylation status of HSP27 on TNF- $\alpha$-stimulated IL- 6 synthesis using mutant HSP27-transfected cells. We used two kinds of mutant HSP27-transfected cells. The 3A cells overexpressed non-phosphorylatable HSP27, and the 3D cells overexpressed mutant-HSP27 mimicking the phosphorylated protein. The level of TNF- $\alpha$-stimulated IL-6 release was significantly higher in the 3D cells than in the $3 \mathrm{~A}$ cells. In addition, we showed that the level of TNF- $\alpha$-stimulated IL- 6 mRNA in the 3D cells was significantly increased compared to that in the $3 \mathrm{~A}$ cells. Thus, it is likely that HSP27 acts upstream of the transcription event in TNF- $\alpha$-induced IL- 6 synthesis. Based on our results, it is probable that phosphorylated HSP27 plays a stimulatory role in the TNF- $\alpha$-induced IL- 6 synthesis in MC3T3-E1 cells.

TNF- $\alpha$ is generally recognized to activate the $\mathrm{I} \kappa \mathrm{B} / \mathrm{NF} \kappa \mathrm{B}$ pathway (39). In our previous studies $(7,8,40)$, we have demonstrated that the activation of p44/p42 MAPK and Akt are involved in TNF- $\alpha$-stimulated IL- 6 synthesis in osteoblast-like MC3T3-E1 cells. Thus, in the present study, we examined the 
TNF- $\alpha$-induced phosphorylation levels of these intracellular signaling molecules, IкB, NFкB, p44/p42 MAPK and Akt in the HSP27-transfected MC3T3-E1 cells. However, we observed no significant differences in their phosphorylation after TNF- $\alpha$ stimulation among the different kinds of transfected cells (empty vector, WT HSP27, non-phosphorylatable HSP27 and phospho-mimic HSP27). Therefore, it seems unlikely that HSP27 regulates TNF- $\alpha$-stimulated IL- 6 synthesis through the activation of I $\mathrm{BB} / \mathrm{NF} \kappa \mathrm{B}, \mathrm{p} 44 / \mathrm{p} 42 \mathrm{MAPK}$ and Akt, or at a point upstream of these molecules.

HSP27 is one of the small HSPs which contain a highly conserved region referred to as the $\alpha$-crystallin domain (21). The $\alpha$-crystallin domain is essential for the oligomerization of HSP27 (42). HSP27 normally exists in an aggregated form, but when it is phosphorylated, it causes a conformational change resulting in its dimerization. It has recently been reported that phosphorylated HSP27 is involved in diabetic kidney disease and viral infections $(43,44)$. We have reported that prostaglandin $\mathrm{D}_{2}$ stimulates the phosphorylation of HSP27 in osteoblast-like MC3T3-E1 cells (9). However, the exact role of HSP27, and the significance of its phosphorylation in bone metabolism has not been fully clarified. In the present study, we showed that TNF- $\alpha$-stimulated IL- 6 synthesis is regulated by the HSP27 expression level and its phosphorylation status in these cells. In our recent study (34), we have reported that HSP27 regulates osteocalcin synthesis in osteoblast-like MC3T3-E1 cells, and have demonstrated that phosphorylated HSP27 changes its localization and acts as a functional regulator of the endoplasmic reticulum, contributing to the modulation of osteocalcin synthesis. Given its effects on osteocalcin, it is probable that the change in the localization of HSP27 due to phosphorylation may contribute to its regulation of TNF- $\alpha$-stimulated IL- 6 synthesis in osteoblasts.

Both TNF- $\alpha$ and IL- 6 are generally recognized as proinflammatory cytokines. In osteoblasts, TNF- $\alpha$ and IL-6 are reported to be bone resorptive agents and play crucial roles in the pathogenesis of postmenopausal osteoporosis and rheumatoid arthritis (10,45-49). The recent development of novel therapies for patients with rheumatoid arthritis, such as a monoclonal antibody against TNF- $\alpha$, has led to suppression of disease activity and clinical symptoms (50).

We have reported that various physiological stimuli induce HSP27 in osteoblast-like MC3T3-E1 cells (29-33). In the present study, we examined whether TNF- $\alpha$ is capable of inducing HSP27, and found that TNF- $\alpha$ alone failed to induce HSP27 in osteoblast-like MC3T3-E1 cells. Although the expression level of HSP27 is reportedly quite low or hardly detectable in unstimulated osteoblasts (28), we herein showed that TNF- $\alpha$-stimulated IL- 6 synthesis was modulated by the HSP27 expression level and/or its phosphorylation status in osteoblast-like MC3T3-E1 cells. It has been shown that osteosarcoma specimens with overexpressed HSP27 are associated with poor prognosis (51). Although rheumatoid arthritis is mainly caused by inflammation of synovial cells, our results suggest that the expression level of HSP27 in osteoblasts may correlate to the clinical symptoms or inflammatory sings of rheumatoid arthritis patients. Thus, our findings regarding the role of HSP27 in osteoblast functions may provide a novel therapeutic target for diseases such as osteoporosis or rheumatoid arthritis. Further investigation is necessary to clarify the precise mechanism of action of HSP27 in osteoblasts and in bone metabolism.

In conclusion, our present results strongly suggest that HSP27 regulates TNF- $\alpha$-stimulated IL-6 synthesis at a point upstream of the transcriptional event in osteoblasts.

\section{Acknowledgements}

We thank Dr C. Schafer for providing the mutant HSP27 cDNA, and Ms. Yoko Kawamura for her skillful technical assistance. This investigation was supported in part by a Grant-in-Aid for Scientific Research (19591042) from the Ministry of Education, Science, Sports and Culture of Japan, the Foundation for Growth Science and a Research Grant for Longevity Sciences (21A-4) from the Ministry of Health, Labour and Welfare of Japan.

\section{References}

1. Locksley RM, Killeen N and Lenardo MJ: The TNF and TNF receptor superfamilies: integrating mammalian biology. Cell 104: 487-501, 2001.

2. Kwan Tat S, Padrines M, Theoleyre S, Heymann D and Fortun Y: IL-6, RANKL, TNF- $\alpha /$ IL-1: interrelations in bone resorption pathophysiology. Cytokine Growth Factor Rev 15: 49-60, 2004.

3. Blair HC, Robinson LJ and Zaidi M: Osteoclast signalling pathways. Biochem Biophys Res Commun 328: 728-738, 2005.

4. Nijweide PJ, Burger EH and Feyen JH: Cells of bone: proliferation, differentiation, and hormonal regulation. Physiol Rev 66: 855-886, 1986.

5. Akira S, Taga T and Kishimoto T: Interleukin-6 in biology and medicine. Adv Immunol 54: 1-78, 1993.

6. Heymann D and Rousselle AV: gp130 Cytokine family and bone cells. Cytokine 12: 1455-1468, 2000.

7. Kozawa O, Tokuda H, Matsuno $\mathrm{H}$ and Uematsu T: Activation of mitogen-activated protein kinase is involved in sphingosine 1-phosphate-stimulated interleukin-6 synthesis in osteoblasts. FEBS Lett 418: 149-151, 1997.

8. Kozawa O, Suzuki A, Kaida T, Tokuda $\mathrm{H}$ and Uematsu T: Tumor necrosis factor- $\alpha$ autoregulates interleukin- 6 synthesis via activation of protein kinase C. Function of sphingosine 1-phosphate and phosphatidylcholine-specific phospholipase C. J Biol Chem 272: 25099-25104, 1997.

9. Takai S, Tokuda H, Hanai Y and Kozawa O: Phosphatidylinositol 3 -kinase/Akt plays a part in tumor necrosis factor- $\alpha$-induced interleukin-6 synthesis in osteoblasts. Horm Metab Res 38: 563-569, 2006.

10. Ishimi Y, Miyaura C, Jin CH, Akatsu T, Abe E, Nakamura Y, Yamaguchi A, Yoshiki S, Matsuda T and Hirano T: IL-6 is produced by osteoblasts and induces bone resorption. J Immunol 145: 3297-3303, 1990.

11. Roodman GD: Interleukin-6: an osteotropic factor? J Bone Miner Res 7: 475-478, 1992.

12. Hendrick JP and Hartl FU: Molecular chaperone functions of heat-shock proteins. Annu Rev Biochem 62: 349-384, 1993.

13. Liu AY, Lin Z, Choi HS, Sorhage F and Li B: Attenuated induction of heat shock gene expression in aging diploid fibroblasts. J Biol Chem 264: 12037-12045, 1989.

14. Taylor RP and Benjamin IJ: Small heat shock proteins: a new classification scheme in mammals. J Mol Cell Cardiol 38: 433-444, 2005.

15. Benjamin IJ and McMillan DR: Stress (heat shock) proteins: molecular chaperones in cardiovascular biology and disease. Circ Res 83: 117-132, 1998.

16. Maloyan A, Sayegh J, Osinska H, Chua BH and Robbins J: Manipulation of death pathways in desmin-related cardiomyopathy. Circ Res 106: 1524-1532, 2010.

17. Martin JL, Mestril R, Hilal-Dandan R, Brunton LL and Dillmann WH: Small heat shock proteins and protection against ischemic injury in cardiac myocytes. Circulation 96: 4343-4348, 1997.

18. van Noort JM, van Sechel AC, Bajramovic JJ, el Ouagmiri M, Polman CH, Lassmann H and Ravid R: The small heat-shock protein $\alpha \mathrm{B}$-crystallin as candidate autoantigen in multiple sclerosis. Nature 375: 798-801, 1995. 
19. Chelouche-Lev D, Kluger HM, Berger AJ, Rimm DL and Price JE: $\alpha \mathrm{B}$-crystallin as a marker of lymph node involvement in breast carcinoma. Cancer 100: 2543-2548, 2004.

20. Kostenko S, Johannessen M and Moens U: PKA-induced F-actin rearrangement requires phosphorylation of $\mathrm{Hsp} 27$ by the MAPKAP kinase MK5. Cell Signal 21: 712-718, 2009.

21. Kostenko S and Moens U: Heat shock protein 27 phosphorylation: kinases, phosphatases, functions and pathology. Cell Mol Life Sci 66: 3289-3307, 2009.

22. Yasuda E, Kumada T, Takai S, Ishisaki A, Noda T, MatsushimaNishiwaki R, Yoshimi N, Kato K, Toyoda H, Kaneoka Y, Yamaguchi A and Kozawa O: Attenuated phosphorylation of heat shock protein 27 correlates with tumor progression in patients with hepatocellular carcinoma. Biochem Biophys Res Commun 337: 337-342, 2005.

23. Tiffee JC, Griffin JP and Cooper LF: Immunolocalization of stress proteins and extracellular matrix proteins in the rat tibia Tissue Cell 32: 141-147, 2000.

24. Leonardi R, Barbato E, Paganelli C and Lo Muzio L: Immunolocalization of heat shock protein 27 in developing jaw bones and tooth germs of human fetuses. Calcif Tissue Int 75: 509-516, 2004

25. Lavoie JN, Gingras-Breton G, Tanguay RM and Landry J: Induction of Chinese hamster HSP27 gene expression in mouse cells confers resistance to heat shock. HSP27 stabilization of the microfilament organization. J Biol Chem 268: 3420-3429, 1993.

26. Blackburn RV, Galoforo SS, Berns CM, Armour EP, McEachern D, Corry PM and Lee YJ: Comparison of tumor growth between hsp25- and hsp27-transfected murine L929 cells in nude mice. Int J Cancer 72: 871-877, 1997.

27. Hedges JC, Dechert MA, Yamboliev IA, Martin JL, Hickey E, Weber LA and Gerthoffer WT: A role for p38(MAPK)/HSP27 pathway in smooth muscle cell migration. J Biol Chem 274 24211-24219, 1999

28. Shakoori AR, Oberdorf AM, Owen TA, Weber LA, Hickey E, Stein JL, Lian JB and Stein GS: Expression of heat shock genes during differentiation of mammalian osteoblasts and promyelocytic leukemia cells. J Cell Biochem 48: 277-287, 1992.

29. Hatakeyama D, Kozawa O, Niwa M, Matsuno H, Kato K Tatematsu N, Shibata T and Uematsu T: Inhibition by adenylyl cyclase-cAMP system of ET-1-induced HSP27 in osteoblasts. Am J Physiol Endocrinol Metab 281: E1260-E1266, 2001.

30. Kozawa O, Otsuka T, Hatakeyama D, Niwa M, Matsuno H, Ito H Kato K, Matsui N and Uematsu T: Mechanism of prostaglandin D2-stimulated heat shock protein 27 induction in osteoblasts. Cell Signal 13: 535-541, 2001.

31. Tokuda H, Kozawa O, Niwa M, Matsuno H, Kato K and Uematsu T: Mechanism of prostaglandin E2-stimulated heat shock protein 27 induction in osteoblast-like MC3T3-E1 cells. J Endocrinol 172 271-281, 2002

32. Tokuda $H$, Niwa $M$, Ishisaki A, Nakajima K, Ito $H$, Kato $K$ and Kozawa O: Involvement of stress-activated protein kinase (SAPK)/c-Jun N-terminal kinase (JNK) in prostaglandin $\mathrm{F}_{2 \alpha}$-induced heat shock protein 27 in osteoblasts. Prostaglandins Leukot Essent Fatty Acids 70: 441-447, 2004.

33. Hayashi K, Takai S, Matsushima-Nishiwaki R, Hanai Y, Kato K, Tokuda $\mathrm{H}$ and Kozawa O: (-)-Epigallocatechin gallate reduces transforming growth factor $\beta$-stimulated HSP27 induction through the suppression of stress-activated protein kinase/c-Jun N-terminal kinase in osteoblasts. Life Sci 82: 1012-1017, 2008.

34. Kato K, Adachi S, Matsushima-Nishiwaki R, Minamitani C, Natsume H, Katagiri Y, Hirose Y, Mizutani J, Tokuda H, Kozawa O and Otsuka T: Regulation by heat shock protein 27 of osteocalcin synthesis in osteoblasts. Endocrinology 152: 1872-1882, 2011.
35. Sudo H, Kodama HA, Amagai Y, Yamamoto S and Kasai S: In vitro differentiation and calcification in a new clonal osteogenic cell line derived from newborn mouse calvaria. J Cell Biol 96: 191-198, 1983.

36. Kozawa O, Suzuki A, Tokuda $\mathrm{H}$ and Uematsu T: Prostaglandin F2 $\alpha$ stimulates interleukin-6 synthesis via activation of PKC in osteoblast-like cells. Am J Physiol 272: E208-E211, 1997.

37. Laemmli UK: Cleavage of structural proteins during the assembly of the head of bacteriophage T4. Nature 227: 680-685, 1970.

38. Kozawa $O$, Niwa M, Matsuno H, Ishisaki A, Kato $K$ and Uematsu T: Stimulatory effect of basic fibroblast growth factor on induction of heat shock protein 27 in osteoblasts: role of protein kinase C. Arch Biochem Biophys 388: 237-242, 2001.

39. Hayden MS and Ghosh S: Signaling to NF-kappaB. Genes Dev 18: 2195-2224, 2004

40. Takai S, Tokuda H, Yoshida M, Yasuda E, MatsushimaNishiwaki R, Harada A, Kato K and Kozawa O: Prostaglandin D2 induces the phosphorylation of HSP27 in osteoblasts: function of the MAP kinase superfamily. Prostaglandins Leukot Essent Fatty Acids 75: 61-67, 2006.

41. Hazzalin CA, Le Panse R, Cano E and Mahadevan LC: Anisomycin selectively desensitizes signalling components involved in stress kinase activation and fos and jun induction. Mol Cell Biol 18: 1844-1854, 1998.

42. Kappe G, Franck E, Verschuure P, Boelens WC, Leunissen JA and de Jong WW: The human genome encodes $10 \alpha$-crystallin-related small heat shock proteins: HspB1-10. Cell Stress Chaperones 8: 53-61, 2003.

43. Singh D, McCann KL and Imani F: MAPK and heat shock protein 27 activation are associated with respiratory syncytial virus induction of human bronchial epithelial monolayer disruption. Am J Physiol Lung Cell Mol Physiol 293: L436-L445, 2007.

44. Barutta F, Pinach S, Giunti S, Vittone F, Forbes JM, Chiarle R, Arnstein M, Perin PC, Camussi G, Cooper ME and Gruden G: Heat shock protein expression in diabetic nephropathy. Am J Physiol Renal Physiol 295: F1817-F1824, 2008.

45. Helle M, Brakenhoff JP,De GrootER and Aarden LA: Interleukin 6 is involved in interleukin 1-induced activities. Eur J Immunol 18: 957-959, 1988.

46. Wei S, Kitaura H, Zhou P, Ross FP and Teitelbaum SL: IL-1 mediates TNF-induced osteoclastogenesis. J Clin Invest 115: 282-290, 2005

47. Mundy GR: Osteoporosis and inflammation. Nutr Rev 65: S147-S151, 2007.

48. Brennan FM and McInnes IB: Evidence that cytokines play a role in rheumatoid arthritis. J Clin Invest 118: 3537-3545, 2008.

49. Marotte H and Miossec P: Prevention of bone mineral density loss in patients with rheumatoid arthritis treated with anti-TNFa therapy. Biologics 2: 663-669, 2008

50. Chen YF, Jobanputra P, Barton P, Jowett S, Bryan S, Clark W, Fry-Smith A and Burls A: A systematic review of the effectiveness of adalimumab, etanercept and infliximab for the treatment of rheumatoid arthritis in adults and an economic evaluation of their cost-effectiveness. Health Technol Assess 10: 1-229, 2006.

51. Uozaki $H$, Horiuchi $H$, Ishida $T$, Iijima $T$, Imamura $T$ and Machinami R: Overexpression of resistance-related proteins (metallothioneins, glutathione-S-transferase pi, heat shock protein 27, and lung resistance-related protein) in osteosarcoma. Relationship with poor prognosis. Cancer 79: 2336-2344, 1997. 